Article

\title{
Association with Ambient Air Pollutants and School Absence Due to Sickness in Schoolchildren: A Case-Crossover Study in a Provincial Town of Japan
}

\author{
Masanari Watanabe ${ }^{1, *}$, Hisashi Noma ${ }^{2} \mathbb{D}$, Jun Kurai ${ }^{1}$, Kazuhiro Kato ${ }^{3}$ and Hiroyuki Sano ${ }^{4}$ \\ 1 Division of Internal Medicine, Motomachi Hospital, 1895-1 Agarimichi-cho, Sakaiminato 684-0033, Japan; \\ junkurajun@gmail.com \\ 2 Department of Data Science, Institute of Statistical Mathematics, 10-3 Midori-cho, Tachikawa, \\ Tokyo 190-8562, Japan; noma@ism.ac.jp \\ 3 Department of Internal Medicine, Yasugi Daiichi Hospital, Yasugicho 899-1, Yasugi 692-0011, Japan; \\ eugene.aleuc@gmail.com \\ 4 Allergy Center, Kindai University Hospital, Ohnohigashi 377-2, Osakasayama 589-0014, Japan; \\ hsano@med.kindai.ac.jp \\ * Correspondence: navijinsei@gmail.com; Tel.: +81-859-44-0101
}

check for updates

Citation: Watanabe, M.; Noma, H.; Kurai, J.; Kato, K.; Sano, H.

Association with Ambient Air Pollutants and School Absence Due to Sickness in Schoolchildren: A Case-Crossover Study in a Provincial Town of Japan. Int. J. Environ. Res. Public Health 2021, 18, 6631. https:// doi.org/10.3390/ijerph18126631

Academic Editor: Paul B. Tchounwou

Received: 21 May 2021

Accepted: 19 June 2021

Published: 20 June 2021

Publisher's Note: MDPI stays neutral with regard to jurisdictional claims in published maps and institutional affiliations.

Copyright: (c) 2021 by the authors. Licensee MDPI, Basel, Switzerland. This article is an open access article distributed under the terms and conditions of the Creative Commons Attribution (CC BY) license (https:// creativecommons.org/licenses/by/ $4.0 /)$.

\begin{abstract}
The effect of ambient air pollutants and Asian dust (AD) on absence from school due to sickness has not been well researched. By conducting a case-crossover study, this study investigated the influence of ambient air pollutants and desert sand dust particles from East Asia on absence from school due to sickness. From November 2016 to July 2018, the daily cases of absence due to sickness were recorded in five elementary schools in Matsue, Japan. During the study period, a total of 16,915 absence cases were recorded, which included 4865 fever cases and 2458 cough cases. The relative risk of overall absence in a $10-\mu \mathrm{g} / \mathrm{m}^{3}$ increment of $\mathrm{PM}_{2.5}$ and a $0.1-\mathrm{km}^{-1}$ of desert sand dust particles from East Asia were found with 1.28 (95\%CI: 1.15-1.42) and 2.15 (1.04-4.45) at lag0, respectively. The significant influence of $\mathrm{PM}_{2.5}$ persisted at lag5 and that of desert sand dust particles at lag2. $\mathrm{NO}_{2}$ had statistically significant effects at lag2, lag3, and lag4. However, there was no evidence of a positive association of $\mathrm{O}_{\mathrm{x}}$ and $\mathrm{SO}_{2}$ with absence from school. These results suggested that $\mathrm{PM}_{2.5}, \mathrm{NO}_{2}$, and AD increased the risk of absence due to sickness in schoolchildren.
\end{abstract}

Keywords: ambient air pollutants; Asian dust; cough; fever; school absence; sickness

\section{Introduction}

As the world gets hotter and more crowded, ambient air pollutants are considered the largest environmental health threat globally [1]. Low- and middle-income countries disproportionately experience this burden compared to the developed countries [2]. Mainland East Asia has undergone rapid industrial development in the recent decades, which has increased ambient air pollutants in the boundary layer and led to this region now being one of the most heavily polluted areas in the world [3-6]. The transboundary transport of ambient air pollutants from the East Asian continent to Japan has contributed to an increase in air pollution levels [7]. Although particulate matter (PM) pollution level has been slowly improving in recent years following the environmental policy by the Chinese government, the average annual level of ozone in Japan remains on an upward trend [7]. Thus, even in developed East Asian countries such as Japan, China, and South Korea, ambient air pollutants continue to be an important health concern.

Among ambient air pollutants, PM, ozone, nitrogen dioxide $\left(\mathrm{NO}_{2}\right)$, and sulphur dioxide $\left(\mathrm{SO}_{2}\right)$ have the strongest evidence for causing various health disorder [8-10]. These have been responsible for 4.2 million deaths globally and are estimated to cause about $16 \%$ of the lung cancer deaths, $25 \%$ of chronic obstructive pulmonary disease (COPD) deaths, about $17 \%$ of ischemic heart disease and stroke, and about $26 \%$ of respiratory infection 
deaths around the world $[1,11]$. In children, ambient air pollutants are an important risk factor for acute and chronic diseases such as respiratory diseases, allergic diseases, cancers, and acute respiratory infections [1,12-17]. Furthermore, they are associated with increased deaths, hospitalisation, and emergency visits. Several studies surveyed the association between ambient air pollutants and school absence [18-23] and found that $\mathrm{PM}$ less than $2.5 \mu \mathrm{m}$ aerodynamic diameters $\left(\mathrm{PM}_{2.5}\right)$ and ozone were associated with school absence [18-22]. Recent studies showed that ambient air pollutants control and environmental regulations can play significant inhibitory roles in their emissions [24] and can reduce adverse health effects $[25,26]$.

Asian dust (AD), originating in the deserts of Mongolia, northern China, and Kazakhstan and often dispersing over East Asia, is also an important health concern in East Asia. Originally, AD was a desert sand dust storm; however, with rapid industrial development in East Asia it has become an important source of ambient air pollutants [27]. Studies have shown that $\mathrm{AD}$ has an influence on mortality, emergency visits, and hospitalisations for diseases such as cardiovascular disease, pneumonia, and asthma in both children and adults [28-32].

Numerous studies found adverse effects of ambient air pollutants and AD on respiratory and cardiovascular diseases and investigated the relationship with a focus on admissions, emergency visits, and hospital visits. However, to the best of our knowledge, there are few reports about the influence of $\mathrm{AD}$ on absence from school due to sickness in schoolchildren. Although a few studies have found an association between them, but they did not investigate the specific causes of the absence $[18,19]$. Thus, many points, specifically, the potential for such absence need further clarification. Children's exposure to ambient air pollutants is a special concern because, when the exposure begins, their immune system and lungs are not fully developed, raising the possibility of different responses than that observed among adults [33]. The aim of this study, therefore, was to investigate the influence of short-term exposure to ambient air pollutants and $\mathrm{AD}$ on absence from school due to sickness among Japanese schoolchildren. Furthermore, this study examined the symptoms to identify the effect of infection and respiratory disorder on absence due to exposure to ambient air pollutants and AD.

\section{Materials and Methods}

\subsection{Study Design}

This study focused on the influence of infection and respiratory disease exposure to ambient air pollutants and desert sand dust particles on absence from school. It used a case-crossover design, which compared the exposure on the case day, that is, when events occurred, with referent days and examined the differences in exposure that contributed to the differences in the daily count of cases. From 1 November 2016 to 20 July 2018, the number of absences due to sickness were recorded in five elementary schools of Matsue City in western Japan. The sickness details were also recorded and divided into eight categories: fever up, headache, cough (respiratory symptom), diarrhoea and abdominal pain (abdominal symptoms), vomiting, rashes, influenza infection, influenza like symptoms defined as having both high fever and upper airway symptoms, and other reasons. These classifications decreased the efforts required by schoolteachers and made taking the survey easier. Multiple answers were accepted as reasons for the absence. Matsue City has a population of approximately 200,000 individuals and covers an area of $530.2 \mathrm{~km}^{2}$. The five elementary schools were within $5 \mathrm{~km}$ of each other, and the students lived within a $1 \mathrm{~km}$ radius of the schools. The study was approved by the Ethics Committee of the Faculty of Medicine, Tottori University (approval number 1607A033).

\subsection{Measurements of The Levels of Air Pollutants, Sand Dust Particles, and Weather Data}

The hourly concentrations of $\mathrm{PM}_{2.5}, \mathrm{SO}_{2}, \mathrm{NO}_{2}$, and photochemical oxidants $\left(\mathrm{O}_{\mathrm{x}}\right)$ are monitored by the Japanese Ministry of the Environment in Matsue City, and these data were obtained from the ministry database. The data of meteorological variables, including 
daily temperature, humidity, and atmospheric pressure, were obtained from the Japan Meteorological Agency.

Light Detection and Ranging (LIDAR) systems measure PM as non-spherical airborne particles, which are equivalent to desert sand dust particles from East Asia; spherical airborne particles, which are equal to air pollution aerosols, are measured by illuminating a target with two laser beams of different wavelengths and analyzing the reflected light [34,35]. Both levels of spherical and non-spherical particles are measured at 15-min intervals, and daily particle levels are determined from the median value of 96 measurements collected over a 24-h period from midnight of the first day to midnight of the following day. LIDAR is used to monitor the concentration of desert sand dust particles from East Asia. For the current analysis, LIDAR data for spherical and non-spherical particles were obtained from the Matsue observatory. Values measured at 120-150 m above the ground, which is the minimum altitude required by LIDAR systems to measure non-spherical and spherical particles, were used.

\subsection{Statistical Methods}

The data set of this study was constructed to facilitate a time-stratified case-crossover analysis [36-38], in which each case acted as its own control. This study adopted the conditional Poisson model to assess associations between time series of environmental exposures and counts of health outcomes with adjustment for overdispersion and autocorrelation. Average temperature, relative humidity, and atmospheric pressure were involved in the Poisson regression model to adjust the potential confounding. In order to combat the potential delayed effects of ambient air pollutants on absence due to sickness, this study used the single-day lags (lag0, lag1, lag2, lag3, lag4, lag5) to estimate the effects of air pollutants at different lag days. Lag1 referred to the concentration of air pollutants on the previous day. The relative risk (RR) and its $95 \%$ confidence interval (CI) for a $10 \mu \mathrm{g} / \mathrm{m}^{3}$ increase in 24-h average concentration of $\mathrm{PM}_{2.5}$, a 1-ppb increase in 24-h average concentration of $\mathrm{NO}_{2}, \mathrm{SO}_{2}$, and $\mathrm{O}_{\mathrm{x}}$ and a $0.1-\mathrm{km}^{-1}$ increment in desert sand dust particles by LIDAR were calculated. A value of $0.1 \mathrm{~km}^{-1}$ in the concentration of desert sand dust particles from East Asia by LIDAR corresponded to $0.1 \mathrm{mg} / \mathrm{m}^{3}$ [39]. Statistical significance was considered only when the $p$-value was smaller than 0.05 .

\section{Results}

The spatial distributions of schools are displayed in Figure 1. All of them were concentrated in the main urban areas of Matsue City. During the study period from 1 November 2016 to 20 July 2018, there were 361 school days in 627 days. The descriptive statistics for the meteorological factors and air pollutants during the study period are summarised in Table 1. Data are shown as mean, median, and quartile.



Figure 1. The spatial distributions of air monitoring sites and elementary schools in Matsue, Japan. 
Table 1. Descriptive statistics for meteorological factors, the concentration of air pollutants and desert sand dust particles by Light Detection and Ranging system from 1 November 2016 to 20 July 2018 in Matsue City, Japan.

\begin{tabular}{ccccccc}
\hline Factors & Mean \pm SD & Min & $\begin{array}{c}\text { 1st } \\
\text { Quartile }\end{array}$ & Median & $\begin{array}{c}\text { 3rd } \\
\text { Quartile }\end{array}$ & Max \\
\hline Daily average temperature $\left({ }^{\circ} \mathrm{C}\right)$ & $14.2 \pm 8.2$ & -2.6 & 7.1 & 13.8 & 21.2 & 32.3 \\
Daily maximum temperature $\left({ }^{\circ} \mathrm{C}\right)$ & $18.6 \pm 8.6$ & -0.3 & 11.2 & 18.7 & 26.1 & 37.7 \\
Daily minimum temperature $\left({ }^{\circ} \mathrm{C}\right)$ & $10.3 \pm 8.3$ & -7.0 & 3.0 & 9.0 & 16.9 & 28.3 \\
Daily average relative humidity $(\%)$ & $75.9 \pm 10.4$ & 43.0 & 69.0 & 76.0 & 83.0 & 98.0 \\
Daily average atmospheric pressure $(\mathrm{hPa})$ & $1013.1 \pm 6.7$ & 992.9 & 1008.0 & 1013.4 & 1018.4 & 1027.9 \\
Daily average $\mathrm{PM}_{2.5}\left(\mu \mathrm{g} / \mathrm{m}^{3}\right)$ & $12.4 \pm 7.2$ & 1.0 & 7.2 & 10.8 & 16.2 & 57.5 \\
Daily maximum $\mathrm{PM}_{2.5}\left(\mu \mathrm{gg} / \mathrm{m}^{3}\right)$ & $24.1 \pm 15.8$ & 2.0 & 13.0 & 21.0 & 30.0 & 134.0 \\
Daily average $\mathrm{SO}_{2}(\mathrm{ppb})$ & $1.0 \pm 1.1$ & 0 & 0.4 & 0.6 & 1.1 & 8.9 \\
Daily maximum $\mathrm{SO}_{2}(\mathrm{ppb})$ & $3.7 \pm 5.7$ & 0.1 & 0.7 & 1.2 & 4.0 & 47.6 \\
Daily average $\mathrm{NO}_{2}(\mathrm{ppb})$ & $2.3 \pm 1.3$ & 0.2 & 1.4 & 2.0 & 2.8 & 12.9 \\
Daily maximum $\mathrm{NO}_{2}(\mathrm{ppb})$ & $4.7 \pm 3.0$ & 0.6 & 2.8 & 3.9 & 5.8 & 32.1 \\
Daily average $\mathrm{O}_{\mathrm{x}}(\mathrm{ppb})$ & $36.3 \pm 13.0$ & 0.8 & 28.8 & 36.5 & 44.1 & 90.6 \\
Daily maximum $\mathrm{O}_{\mathbf{x}}(\mathrm{ppb})$ & $50.4 \pm 16.7$ & 0.17 & 41.7 & 48.6 & 58.7 & 120.6 \\
Desert sand dust particles & $0.018 \pm$ & 0 & 0.008 & 0.012 & 0.019 & 0.233 \\
$\left(\mathrm{~km}^{-1}\right)$ & 0.022 & & & & & \\
\hline
\end{tabular}

$\mathrm{SD}$, standard deviation; $\mathrm{PM}_{2.5}$, particulate matter less than $2.5 \mu \mathrm{m}$ aerodynamic diameters; $\mathrm{SO}_{2}$, sulfur dioxide; $\mathrm{NO}_{2}$, nitrogen dioxide; and $\mathrm{O}_{\mathrm{x}}$, photochemical oxidants.

Table 2 shows the results of the spearman rank correlation between average levels of air pollutants and meteorological factors. $\mathrm{PM}_{2.5}$, desert sand dust particles, and $\mathrm{SO}_{2}$ had significant relationships with $\mathrm{NO}_{2}$ and $\mathrm{O}_{x}$. A significant correlation coefficient between $\mathrm{NO}_{2}$ and $\mathrm{O}_{\mathrm{x}}$ was not observed. $\mathrm{SO}_{2}, \mathrm{NO}_{2}$, and desert sand dust particles had significantly negative correlations with temperature, while there was a significantly positive relationship between $\mathrm{PM}_{2.5}$ and temperature.

Table 2. The coefficient of spearman rank correlation between air pollutants and meteorological factors in Matsue City, Japan.

\begin{tabular}{cccccccc}
\hline Factors & $\mathbf{P M}_{2.5}$ & $\mathbf{S O}_{2}$ & $\mathbf{N O}_{2}$ & $\mathbf{O}_{\mathbf{x}}$ & DSDP & TEM & RHU \\
\hline $\mathrm{PM}_{2.5}$ & 1 & & & & & & \\
$\mathrm{SO}_{2}$ & $0.26^{*}$ & 1 & & & & & \\
$\mathrm{NO}_{2}$ & $0.36^{*}$ & $0.35^{*}$ & 1 & & & & \\
$\mathrm{O}_{\mathbf{x}}$ & $0.18^{*}$ & $0.09^{*}$ & -0.02 & 1 & & & \\
$\mathrm{DSDP}$ & $0.49^{*}$ & $0.23^{*}$ & $0.23^{*}$ & $0.48^{*}$ & 1 & & \\
$\mathrm{TEM}$ & $0.21^{*}$ & $-0.26^{*}$ & $-0.42^{*}$ & $-0.09^{*}$ & $-0.09 *$ & 1 & \\
$\mathrm{RHU}$ & $-0.14^{*}$ & $-0.15^{*}$ & $0.17^{*}$ & $-0.44^{*}$ & $-0.39 *$ & -0.01 & 1 \\
ATP & -0.04 & $0.16^{*}$ & $0.38^{*}$ & $-0.12^{*}$ & 0.01 & $-0.66^{*}$ & $-0.12^{*}$ \\
\hline
\end{tabular}

$\mathrm{PM}_{2.5}$, particulate matter less than $2.5 \mu \mathrm{m}$ aerodynamic diameters; $\mathrm{SO}_{2}$, sulfur dioxide; $\mathrm{NO}_{2}$, nitrogen dioxide; and $\mathrm{O}_{\mathrm{x}}$, photochemical oxidants; DSDP, desert sand dust particles; TEM, temperature; RHU, relative humidity; ATP, atmospheric pressure; ${ }^{*} p<0.05$.

During the study period, there were 266 school holidays in 627 days. Table 3 shows the total number of absences from school during the study period and due to fever and respiratory symptoms. The study included a total of 16,915 absence cases from school, of which 4865 were for fever and 2458 were for cough (as a respiratory symptom). The most common cause was an influenza infection which resulted in 5266 absences. The other causes were 1441 for headache, 1742 for abdominal symptoms, 981 for vomiting, 187 for influenza-like symptoms, and 50 for rashes. One thousand four hundred fifty-six cases were other causes. Daily mean absence cases were 47.0 for total, of which 13.5 were for fever and 6.8 were for cough. 
Table 3. Descriptive statistics for daily absence cases from school in overall, fever and cough.

\begin{tabular}{|c|c|c|c|c|c|c|c|}
\hline Factors & Total & Mean \pm SD & Min & 1st Quartile & Median & 3rd Quartile & Max \\
\hline Overall (n) & 16,915 & $47.0 \pm 37.3$ & 4 & 26 & 33 & 51 & 258 \\
\hline Fever $(n)$ & 4,865 & $13.5 \pm 7.2$ & 0 & 9 & 12 & 16 & 52 \\
\hline Cough $(n)$ & 2,458 & $6.8 \pm 4.5$ & 0 & 4 & 6 & 9 & 35 \\
\hline
\end{tabular}

SD, standard deviation.

The relative risk of an influence of air pollutants and desert sand dust particles on the overall cases of absence from school by single-pollutant models at different lags are presented in Table 4. A $10-\mu \mathrm{g} / \mathrm{m}^{3}$ increment in $24 \mathrm{~h}$ average concentration of $\mathrm{PM}_{2.5}$ was found at lag0 with 1.28 (95\%CI: $1.15-1.42)$ and a $0.1-\mathrm{km}^{-1}$ increment in desert sand dust particles at lag0 with 2.15 (1.04-4.45). There was significant evidence of a positive association of $\mathrm{PM}_{2.5}$ and desert sand dust particles with overall cases of absence from school. These significant influences of $\mathrm{PM}_{2.5}$ on overall cases of absence persisted at lag5 and that of desert sand dust particles at lag2. Increased $\mathrm{NO}_{2}$ had a statistically significant effect at lag2 with 1.07 (1.02-1.13), lag 3 with 1.08 (1.04-1.13), and lag 4 with 1.04 (1.00-1.08). On the contrary, there was no evidence of a positive association of $\mathrm{O}_{\mathrm{x}}$ and $\mathrm{SO}_{2}$ with overall absence from school.

Table 4. Estimated relative risk and 95\% confidence interval for overall absence from school due to sickness associated with a $10-\mu \mathrm{g} / \mathrm{m}^{3}$ increase in $\mathrm{PM}_{2.5}$, a 1-ppb in $\mathrm{NO}_{2}, \mathrm{SO}_{2}$ and $\mathrm{O}_{\mathrm{x}}$ and a $0.1-\mathrm{km}^{-1}$ in desert sand dust particles.

\begin{tabular}{cccccc}
\hline Lag days & $\mathbf{P M}_{\mathbf{2 . 5}}$ & $\mathbf{S O}_{\mathbf{2}}$ & $\mathbf{N O}_{\mathbf{2}}$ & $\mathbf{O}_{\mathbf{x}}$ & $\begin{array}{c}\text { Desert Sand } \\
\text { Dust Particles }\end{array}$ \\
\hline \multirow{2}{*}{ Lag0 } & $1.28 \S$ & 1.03 & 1.03 & 1.00 & $2.15^{*}$ \\
& $(1.15,1.42)$ & $(0.99,1.08)$ & $(0.98,1.08)$ & $(0.99,1.01)$ & $(1.04,4.45)$ \\
Lag1 & $1.31 \S$ & 1.02 & 1.02 & 0.99 & $2.46^{* *}$ \\
& $(1.17,1.46)$ & $(0.97,1.06)$ & $(0.97,1.07)$ & $(0.98,1.01)$ & $(1.27,4.79)$ \\
Lag2 & $1.32 \S$ & 0.95 & $1.07 *$ & 0.99 & 1.29 \\
& $(1.18,1.48)$ & $(0.90,1.01)$ & $(1.02,1.13)$ & $(0.98,1.00)$ & $(0.79,2.10)$ \\
Lag3 & $1.23 \S$ & 0.96 & $1.08 \S$ & 0.99 & $1.71^{*}$ \\
& $(1.11,1.37)$ & $(0.92,1.01)$ & $(1.04,1.13)$ & $(0.98,1.00)$ & $(1.03,2.84)$ \\
Lag4 & $1.22 \S$ & 1.02 & $1.04 *$ & 1.00 & 1.45 \\
& $(1.10,1.36)$ & $(0.97,1.08)$ & $(1.00,1.08)$ & $(0.99,1.01)$ & $(0.84,2.48)$ \\
Lag5 & $1.25 \S$ & 0.99 & 1.03 & 1.00 & 1.57 \\
& $(1.11,1.40)$ & $(0.95,1.05)$ & $(0.99,1.07)$ & $(0.99,1.01)$ & $(0.89,2.76)$ \\
\hline
\end{tabular}

$\mathrm{PM}_{2.5}$, particulate matter less than $2.5 \mu \mathrm{m}$ aerodynamic diameters; $\mathrm{SO}_{2}$, sulfur dioxide; $\mathrm{NO}_{2}$, nitrogen dioxide; and $\mathrm{O}_{\mathrm{x}}$, photochemical oxidants; ${ }^{*} p<0.05 ;{ }^{* *} p<0.01 ; § p<0.001$.

The influence of air pollutants and desert sand dust particles on absence from school due to fever and cough are shown in Tables 5 and 6, respectively. There were significant associations between $\mathrm{PM}_{2.5}$ and absence from school due to fever from lag0 to lag1, and a significant influence of desert sand dust particles on absence from school due to fever had at lag0 and lag1. On the contrary, cough was significantly associated with $\mathrm{PM}_{2.5}$ at $\operatorname{lag} 0$ and lag 1 and desert sand dust particles at lag $0 . \mathrm{NO}_{2}$ had a statistically significant association with absence due to fever at lag3 and cough from lag3 to lag5. $\mathrm{SO}_{2}$ was significantly associated with respiratory symptom at lag0. There was no evidence of a positive association of $\mathrm{O}_{\mathrm{x}}$ with both cough and fever. 
Table 5. Estimated relative risk and $95 \%$ confidence interval for absence from school due to fever associated with a $10-\mu \mathrm{g} / \mathrm{m}^{3}$ increase in $\mathrm{PM}_{2.5}$, a 1-ppb in $\mathrm{NO}_{2}, \mathrm{SO}_{2}$ and $\mathrm{O}_{\mathrm{x}}$ and a $0.1-\mathrm{km}^{-1}$ in desert sand dust particles.

\begin{tabular}{cccccc}
\hline Lag Days & $\mathbf{P M}_{\mathbf{2 . 5}}$ & $\mathbf{S O}_{\mathbf{2}}$ & $\mathbf{N O}_{\mathbf{2}}$ & $\mathbf{O}_{\mathbf{x}}$ & $\begin{array}{c}\text { Desert Sand } \\
\text { Dust Particles }\end{array}$ \\
\hline \multirow{2}{*}{ Lag0 } & $1.20^{* *}$ & 0.99 & 1.04 & 1.00 & $2.92^{* *}$ \\
& $(1.07,1.36)$ & $(0.94,1.05)$ & $(0.98,1.10)$ & $(0.99,1.01)$ & $(1.33,6.41)$ \\
Lag1 & $1.22^{* *}$ & 1.00 & 1.03 & 1.00 & $3.32^{* *}$ \\
& $(1.08,1.38)$ & $(0.95,1.06)$ & $(0.96,1.09)$ & $(0.98,1.01)$ & $(1.49,7.38)$ \\
Lag2 & $1.25^{\S}$ & 0.95 & 1.06 & 0.99 & 1.22 \\
& $(1.11,1.42)$ & $(0.89,1.02)$ & $(0.99,1.13)$ & $(0.98,1.01)$ & $(0.71,2.09)$ \\
Lag3 & $1.17^{*}$ & 0.95 & $1.09^{* *}$ & 0.99 & 1.31 \\
& $(1.04,1.33)$ & $(0.89,1.02)$ & $(1.03,1.15)$ & $(0.98,1.01)$ & $(0.76,2.29)$ \\
Lag4 & $1.18^{*}$ & 1.04 & 1.02 & 1.01 & 1.27 \\
& $(1.04,1.34)$ & $(0.97,1.11)$ & $(0.96,1.07)$ & $(0.99,1.02)$ & $(0.66,2.45)$ \\
Lag5 & $1.26^{* *}$ & 0.96 & 1.00 & 1.01 & 1.41 \\
& $(1.09,1.45)$ & $(0.89,1.03)$ & $(0.94,1.06)$ & $(0.99,1.02)$ & $(0.70,2.85)$ \\
\hline
\end{tabular}

$\mathrm{PM}_{2.5}$, particulate matter less than $2.5 \mu \mathrm{m}$ aerodynamic diameters; $\mathrm{SO}_{2}$, sulfur dioxide; $\mathrm{NO}_{2}$, nitrogen dioxide; and $\mathrm{O}_{\mathrm{x}}$, photochemical oxidants; * $p<0.05 ;{ }^{* *} p<0.01 ;{ }^{\S} p<0.001$.

Table 6. Estimated relative risk and $95 \%$ confidence interval for absence from school due to cough associated with a $10-\mu \mathrm{g} / \mathrm{m}^{3}$ increase in $\mathrm{PM}_{2.5}$, a 1-ppb in $\mathrm{NO}_{2}, \mathrm{SO}_{2}$ and $\mathrm{O}_{\mathrm{x}}$ and a $0.1-\mathrm{km}^{-1}$ in desert sand dust particles.

\begin{tabular}{|c|c|c|c|c|c|}
\hline Lag Days & $\mathbf{P M}_{2.5}$ & $\mathrm{SO}_{2}$ & $\mathrm{NO}_{2}$ & $\mathrm{O}_{\mathbf{x}}$ & $\begin{array}{c}\text { Desert Sand } \\
\text { Dust Particles }\end{array}$ \\
\hline Lag0 & $\begin{array}{c}1.18 * \\
(1.01,1.37)\end{array}$ & $\begin{array}{c}1.06^{*} \\
(1.01,1.13)\end{array}$ & $\begin{array}{c}1.06 \\
(0.99,1.13)\end{array}$ & $\begin{array}{c}1.01 \\
(0.99,1.02)\end{array}$ & $\begin{array}{c}2.70 * \\
(1.05,6.94)\end{array}$ \\
\hline Lag1 & $\begin{array}{c}1.18 * \\
(1.01,1.38)\end{array}$ & $\begin{array}{c}1.03 \\
(0.97,1.10)\end{array}$ & $\begin{array}{c}1.02 \\
(0.95,1.10)\end{array}$ & $\begin{array}{c}1.01 \\
(0.99,1.02)\end{array}$ & $\begin{array}{c}2.07 \\
(0.77,5.54)\end{array}$ \\
\hline Lag2 & $\begin{array}{c}1.08 \\
(0.92,1.25)\end{array}$ & $\begin{array}{c}1.03 \\
(0.96,1.11)\end{array}$ & $\begin{array}{c}1.03 \\
(0.96,1.11)\end{array}$ & $\begin{array}{c}1.01 \\
(0.99,1.02)\end{array}$ & $\begin{array}{c}0.97 \\
(0.45,2.12)\end{array}$ \\
\hline Lag3 & $\begin{array}{c}1.02 \\
(0.88,1.18)\end{array}$ & $\begin{array}{c}0.98 \\
(0.91,1.06)\end{array}$ & $\begin{array}{c}1.09 * \\
(1.02,1.16)\end{array}$ & $\begin{array}{c}1.00 \\
(0.99,1.02)\end{array}$ & $\begin{array}{c}1.34 \\
(0.65,2.75)\end{array}$ \\
\hline Lag4 & $\begin{array}{c}1.17 \\
(1.00,1.37)\end{array}$ & $\begin{array}{c}0.97 \\
(0.88,1.06)\end{array}$ & $\begin{array}{c}1.12 * * \\
(1.04,1.20)\end{array}$ & $\begin{array}{c}1.01 \\
(0.99,1.02)\end{array}$ & $\begin{array}{c}0.87 \\
(0.41,1.85)\end{array}$ \\
\hline Lag5 & $\begin{array}{c}1.10 \\
(0.93,1.30)\end{array}$ & $\begin{array}{c}0.99 \\
(0.90,1.08)\end{array}$ & $\begin{array}{c}1.13 \S \\
(1.05,1.22)\end{array}$ & $\begin{array}{c}1.01 \\
(0.99,1.02)\end{array}$ & $\begin{array}{c}0.82 \\
(0.34,2.00)\end{array}$ \\
\hline
\end{tabular}

$\mathrm{PM}_{2.5}$, particulate matter less than $2.5 \mu \mathrm{m}$ aerodynamic diameters; $\mathrm{SO}_{2}$, sulfur dioxide; $\mathrm{NO}_{2}$, nitrogen dioxide; and $\mathrm{O}_{\mathrm{x}}$, photochemical oxidants; * $p<0.05 ;{ }^{* *} p<0.01 ;{ }^{\S} p<0.001$.

The relative risks of influence of $\mathrm{PM}_{2.5}$ and desert sand dust particles on the overall cases of absence at lag1 were higher than at lag0. In order to adjust for other pollutants, a two-pollutant model analysis at lag1 was performed in Table 7. The relative risks for the overall cases of absence in $\mathrm{PM}_{2.5}$ and desert sand dust particles appeared to be statistically significant, which was similar to the results of the single-pollutant models. However, for absence due to fever, the relative risks in $\mathrm{PM}_{2.5}$ appeared to be statistically insignificant after adjusting for desert sand dust particles. On the contrary, desert sand dust particles were similar to the results of single-pollutant models. In the results of absence due to cough, the relative risks of $\mathrm{PM}_{2.5}$ tended to be statistically significant adjusting for $\mathrm{O}_{\mathrm{x}}$ and desert sand dust particles. The relative risks of desert sand dust particles on absence due to cough appeared to be statistically insignificant after adjusting for other air pollutants. 
Table 7. Estimated relative risk and $95 \%$ confidence interval for absence associated with a $10-\mu \mathrm{g} / \mathrm{m}^{3}$ increase in $\mathrm{PM}_{2.5}$, a 1-ppb in $\mathrm{NO}_{2}, \mathrm{SO}_{2}$ and $\mathrm{O}_{\mathrm{x}}$ and a $0.1-\mathrm{km}^{-1}$ in desert sand dust particles at lag1 in two-pollutant models.

\begin{tabular}{|c|c|c|c|c|c|}
\hline Variable & $\mathrm{PM}_{2.5}$ & $\mathrm{O}_{\mathrm{x}}$ & $\mathrm{NO}_{2}$ & $\mathrm{SO}_{2}$ & $\begin{array}{l}\text { Desert Sand } \\
\text { Dust Particles }\end{array}$ \\
\hline \multicolumn{6}{|c|}{ Over all absence } \\
\hline Adjusted for $\mathrm{PM}_{2.5}$ & - & $\begin{array}{c}1.00 \\
(0.99,1.00)\end{array}$ & $\begin{array}{c}0.98 \\
(0.94,1.04)\end{array}$ & $\begin{array}{c}1.01 \\
(0.97,1.05)\end{array}$ & $\begin{array}{c}1.84 \\
(0.97,3.47)\end{array}$ \\
\hline Adjusted for $\mathrm{O}_{x}$ & $\begin{array}{c}1.30 \\
(1.17,1.45)\end{array}$ & - & $\begin{array}{c}1.00 \\
(0.94,1.07)\end{array}$ & $\begin{array}{c}1.03 \\
(0.98,1.08)\end{array}$ & $\begin{array}{c}2.66 \\
(1.37,5.17)\end{array}$ \\
\hline Adjusted for $\mathrm{NO}_{2}$ & $\begin{array}{c}1.32 \\
(1.17,1.50)\end{array}$ & $\begin{array}{c}0.99 \\
(0.98,1.01)\end{array}$ & - & $\begin{array}{c}1.02 \\
(0.97,1.07)\end{array}$ & $\begin{array}{c}2.30 \\
(1.17,4.52)\end{array}$ \\
\hline Adjusted for $\mathrm{SO}_{2}$ & $\begin{array}{c}1.30 \\
(1.16,1.45)\end{array}$ & $\begin{array}{c}0.99 \\
(0.98,1.00)\end{array}$ & $\begin{array}{c}1.02 \\
(0.97,1.08)\end{array}$ & - & $\begin{array}{c}2.39 \\
(1.25,4.57)\end{array}$ \\
\hline $\begin{array}{l}\text { Adjusted for desert } \\
\text { sand dust particles }\end{array}$ & $\begin{array}{c}1.30 \\
(1.12,1.51)\end{array}$ & $\begin{array}{c}0.99 \\
(0.98,1.00)\end{array}$ & $\begin{array}{c}1.10 \\
(1.03,1.19)\end{array}$ & $\begin{array}{c}1.04 \\
(0.97,1.11)\end{array}$ & - \\
\hline \multicolumn{6}{|c|}{ Absence due to fever } \\
\hline Adjusted for $\mathrm{PM}_{2.5}$ & - & $\begin{array}{c}1.00 \\
(0.99,1.01)\end{array}$ & $\begin{array}{c}1.00 \\
(0.94,1.07)\end{array}$ & $\begin{array}{c}1.00 \\
(0.94,1.05)\end{array}$ & $\begin{array}{c}2.74 \\
(1.21,6.18)\end{array}$ \\
\hline Adjusted for $\mathrm{O}_{\mathrm{x}}$ & $\begin{array}{c}1.22 \\
(1.08,1.38)\end{array}$ & - & $\begin{array}{c}1.02 \\
(0.95,1.09)\end{array}$ & $\begin{array}{c}1.01 \\
(0.96,1.07)\end{array}$ & $\begin{array}{c}3.67 \\
(1.62,8.32)\end{array}$ \\
\hline Adjusted for $\mathrm{NO}_{2}$ & $\begin{array}{c}1.19 \\
(1.03,1.37)\end{array}$ & $\begin{array}{c}1.00 \\
(0.98,1.01)\end{array}$ & - & $\begin{array}{c}1.01 \\
(0.95,1.07)\end{array}$ & $\begin{array}{c}2.59 \\
(1.12,5.99)\end{array}$ \\
\hline Adjusted for $\mathrm{SO}_{2}$ & $\begin{array}{c}1.22 \\
(1.08,1.39)\end{array}$ & $\begin{array}{c}1.00 \\
(0.99,1.01)\end{array}$ & $\begin{array}{c}1.03 \\
(0.96,1.10)\end{array}$ & - & $\begin{array}{c}3.43 \\
(1.49,7.90)\end{array}$ \\
\hline $\begin{array}{l}\text { Adjusted for desert } \\
\text { sand dust particles }\end{array}$ & $\begin{array}{c}1.15 \\
(0.98,1.36)\end{array}$ & $\begin{array}{c}0.99 \\
(0.98,1.00)\end{array}$ & $\begin{array}{c}1.09 \\
(1.01,1.19)\end{array}$ & $\begin{array}{c}0.99 \\
(0.92,1.07)\end{array}$ & - \\
\hline Adjusted for $\mathrm{PM}_{2.5}$ & \multicolumn{3}{|c|}{ Absence due to cough } & $\begin{array}{c}1.03 \\
(0.97 .1 .09)\end{array}$ & $\begin{array}{c}1.63 \\
(0.63,4.27)\end{array}$ \\
\hline Adjusted for $\mathrm{O}_{x}$ & $\begin{array}{c}1.19 \\
(1.01,1.39)\end{array}$ & $\begin{array}{c}(0.94,1.02) \\
-\end{array}$ & $\begin{array}{c}1.06 \\
(0.97,1.16)\end{array}$ & $\begin{array}{c}1.03 \\
(0.96,1.09)\end{array}$ & $\begin{array}{c}2.07 \\
(0.76,5.64)\end{array}$ \\
\hline Adjusted for $\mathrm{NO}_{2}$ & $\begin{array}{c}1.16 \\
(0.97,1.39)\end{array}$ & $\begin{array}{c}1.02 \\
(1.00,1.03)\end{array}$ & - & $\begin{array}{c}1.03 \\
(0.97,1.10)\end{array}$ & $\begin{array}{c}2.28 \\
(0.79,6.60)\end{array}$ \\
\hline Adjusted for $\mathrm{SO}_{2}$ & $\begin{array}{c}1.16 \\
(0.991 .36)\end{array}$ & $\begin{array}{c}1.00 \\
(0.99,1.02)\end{array}$ & $\begin{array}{c}1.03 \\
(0.96,1.11)\end{array}$ & - & $\begin{array}{c}1.80 \\
(0.67,4.85)\end{array}$ \\
\hline $\begin{array}{l}\text { Adjusted for desert } \\
\text { sand dust particles }\end{array}$ & $\begin{array}{c}1.31 \\
(1.05,1.65)\end{array}$ & $\begin{array}{c}1.000 \\
(0.98,1.02)\end{array}$ & $\begin{array}{c}1.03 \\
(0.92,1.15)\end{array}$ & $\begin{array}{c}1.05 \\
(0.96,1.15)\end{array}$ & - \\
\hline
\end{tabular}

$\mathrm{PM}_{2.5}$, particulate matter less than $2.5 \mu \mathrm{m}$ aerodynamic diameters; $\mathrm{SO}_{2}$, sulfur dioxide; $\mathrm{NO}_{2}$, nitrogen dioxide; and $\mathrm{O}_{\mathrm{x}}$, photochemical oxidants.

Table 8 shows the relative risk for a 10-unit increment of each meteorological factor on the overall cases of absence from schools, depending on levels of temperature, relative humidity, and atmospheric pressure. For temperature and the overall cases of absence, the association was both negative and statistically significant with an estimated reduction in risk of $0.72(0.56-0.92)$ at lag4 and $0.71(0.56-0.91)$ at lag5 per $10^{\circ} \mathrm{C}$ increase. A significant relationship between the overall cases of absence and relative humidity was found at lag5 with $1.08(1.01-1.15)$ per $10 \%$ increase. The increase in atmospheric pressure had a statistically significant effect at lag3 with 1.21 (1.05-0.92) and lag4 with 1.21 (1.08-1.38).

Table 8. Estimated relative risk and 95\% confidence interval for overall absence from school due to sickness associated with a $10{ }^{\circ} \mathrm{C}$ increase in daily average of temperature, a $10 \%$ in relative humidity, and a $10 \mathrm{hPa}$ in atmospheric pressure.

\begin{tabular}{cccc}
\hline Lag Days & Temperature $\left({ }^{\circ} \mathbf{C}\right)$ & Relative Humidity (\%) & Atmospheric Pressure (hPa) \\
\hline Lag0 & 0.86 & 1.03 & 0.96 \\
Lag1 & $(0.67,1.10)$ & $(0.97,1.10)$ & $(0.86,1.08)$ \\
Lag2 & 0.89 & 1.00 & $(0.81,1.04)$ \\
& $(0.69,1.13)$ & $(0.95,1.06)$ & 0.98 \\
Lag3 & 0.89 & 0.97 & $(0.86,1.12)$ \\
Lag4 & $(0.70,1.13)$ & $(0.92,1.02)$ & $\left(1.21^{*}, 1.38\right)$ \\
Lag5 & 0.88 & 0.95 & $1.22 *$ \\
& $(0.69,1.13)$ & $(0.90,1.01)$ & $(1.08,1.38)$ \\
\end{tabular}




\section{Discussion}

Previous studies have unmasked the deleterious effects of ambient air pollutants and $\mathrm{AD}$ on emergency visits and hospitalisation for diseases in children. This evidence would predict that ambient air pollutants and AD may increase absence from school due to sickness in schoolchildren. However, the epidemiologic evidence focusing on their effects on children's absence from school remains limited. Therefore, the present study investigated the relationship between absence from school and air pollutants and desert sand dust particles from East Asia among schoolchildren. $\mathrm{PM}_{2.5}, \mathrm{NO}_{2}$, and desert sand dust particles had statistically significant adverse effects on the overall absence cases from school due to sickness; they were also associated with cough and fever. These results suggest that exposure to $\mathrm{PM}_{2.5}, \mathrm{NO}_{2}$, and $\mathrm{AD}$ have an impact on absence in the western part of Japan. Important causes of absence induced by $\mathrm{PM}_{2.5}, \mathrm{NO}_{2}$, and $\mathrm{AD}$, may be infections and respiratory disorders.

Respiratory tract infection and disease are common causes for hospitalisation and emergency visits due to exposure to ambient air pollutants. An accurate diagnosis was unable to be made because this study was based on the declaration from schoolchildren and their guardians. Therefore, we defined infection based on the presence of fever because fever is the most important symptom in infection. We made a diagnosis of respiratory disease in case the absence from school was due to cough, which was categorised as a respiratory symptom because cough is one of the most important symptoms in respiratory disease. $\mathrm{PM}_{2.5}$ and desert sand dust particles had significant associations with both cough and fever. Infection and respiratory disease, including acute respiratory disease and exacerbation of chronic respiratory disease such as asthma, may be important causes of absence from school due to exposure to $\mathrm{PM}_{2.5}$ and desert sand dust particles.

The emission of ambient air pollutants over neighbouring areas and foreign countries is important in association with ambient air pollutants and health [24,40]. The sum of the contribution from foreign anthropogenic sources is larger than domestic contribution in most areas of Japan, excluding the Kanto region, which is the Greater Tokyo Area encompassing seven prefectures [40]. This study found a significant relationship between desert sand dust particles and other ambient air pollutants, suggesting that foreign ambient air pollutants had impacted that area. Exposure to ambient air pollutants in children is a special concern because their immune system and lungs are not fully developed when the exposure begins, raising the possibility of different responses than that observed among adults [33]. Additionally, children spend more time outside, where the concentrations of pollution from traffic, powerplants, and other combustion sources are generally higher [33]. Although ambient air pollutants have long been thought to exacerbate minor acute illnesses, recent studies have suggested that such pollutants, particularly traffic-related pollution, are associated with infant mortality and the development of asthma and atopy $[25,26,33,41]$. Some $93 \%$ of children and teens younger than 15 years worldwide are exposed to ambient air pollutants with PM levels higher than the limits prescribed in the WHO air quality guidelines [42]. Improvements in air quality, which can be achieved through regional and international cooperation in environmental control and informal regulation, will be beneficial to children worldwide $[24,26]$.

Although the present study also surveyed absence due to headache, abdominal symptoms, vomiting, rash, influenza infection, influenza-like symptoms, and others, its primary outcome focuses on the influence of infection and respiratory disease. Few studies have reported the influence of ambient air pollutants on digestive diseases. Hence, these classifications were included to reduce schoolteachers' efforts on their routine survey. Accordingly, the current study did not focus on the relative risk of the influence of ambient air pollutants and desert sand dust particles on cases of absence from school for these symptoms.

LIDAR systems can measure the amount of AD particles transported for long distances from East Asia to Japan because they are simultaneously applied within $<1 \mathrm{~km}$ above the ground, and the measurements are continuously obtained from various locations in Japan, South Korea, China, Mongolia, and Thailand [34,35]. Accordingly, the levels of desert sand 
dust particles (non-spherical airborne particles) measured by LIDAR measurements are equivalent to the quantity of AD particles. There was significant evidence of a positive association of desert sand dust particles with absence from school in the overall cases and cases of fever and acute respiratory symptoms. These findings suggest that AD is able to increase absence from school through deteriorating infection and respiratory disease.

As well as ambient air pollutants, meteorological factors such as temperature, humidity, and ambient air pollutants are a few of the potentially modifiable environmental risk factors that do not depend on the change of individual behaviours. Several studies reported that there were interactions between ambient air pollutants and temperature on emergency department visits and hospitalisation [43,44]. Therefore, average temperature, relative humidity, and atmospheric pressure were included in the model to control the confounding effects of meteorological factors on the association between ambient air pollutants, which included desert sand dust particles, and absence from school. The present study also analysed the effects of the meteorological factors on absence from school and found statistical significances. $\mathrm{PM}_{2.5}$ and desert sand dust particles were significantly associated with absence from school in lag0, lag1, and lag2, but the significant relative risk for meteorological factors on absence from school lacked in lag0, lag1, and lag2. Meteorological factors did not affect interactions between ambient air pollutants, desert sand dust particles, and absence from school due to sickness.

The present study did not include other meteorological factors like rain and wind speed into the models, because there is little evidence supporting the associations between them and getting sick. The influence of the daily amount of precipitation and wind speed on absence from school due to being sick was analysed. However, absence from school was not associated with the daily amount of precipitation and wind speed.

This study has several limitations. First, the data of ambient air pollutants and meteorological factors in this study was obtained from one fixed monitoring station in Matsue City, which could not represent the total exposure to schoolchildren. Second, we were unable to calculate the personal exposure to ambient air pollutants and desert sand dust particles including ambient and indoor. Due to a lack of calculating the minute exposure to ambient air pollutants and desert sand dust particles in an individual, our study might underestimate or overestimate the effects of ambient air pollutants and desert sand dust particles on absence from school due to being sick. Third, being sick was based on a system of self-report and not confirmed by physicians and hence may include cases of feigned sickness. This study might overestimate the effects of ambient air pollutants and desert sand dust particles on absence from school due to being sick. Fourth, this study was lacking in data during long vacations such as summer and winter vacation. The concentration of $\mathrm{O}_{x}$ is highest in summer than in other seasons. Therefore, this study might underestimate the influence of $\mathrm{O}_{x}$ on absence from school due to being sick. Finally, this study was unable to assess the characteristics of the schoolchildren. A number of studies have found differences in the influence of ambient air pollutants on health between children with and without disease such as asthma. Prevalence rate various disease, especially respiratory disease, in schoolchildren influenced the outcome.

\section{Conclusions}

The present study evaluated the effects of $\mathrm{PM}_{2.5}, \mathrm{NO}_{2}$, and desert sand dust particles from East Asia on the overall absence of children from school due to sickness. Furthermore, this study observed positive associations of $\mathrm{PM}_{2.5}, \mathrm{NO}_{2}$, and desert sand dust particles with absence from school due to fever and cough. Healthy development during childhood is important for later life well-being, and sincere efforts for the reduction of air pollution are required to protect child health. 
Author Contributions: M.W., J.K., and H.S. conceived and designed the study. M.W., H.N., J.K. and H.S. wrote the manuscript. M.W., J.K., K.K., and H.S. contributed to data collection. M.W. and H.N. performed the statistical analysis and interpretation of the results. M.W., H.N., J.K. and H.S. contributed to critical revision of important intellectual content. All authors have read and agreed to the published version of the manuscript.

Funding: This work was supported by JSPS KAKENHI Grant Number JP16K00571.

Institutional Review Board Statement: The study was conducted according to the guidelines of the Declaration of Helsinki, and approved by the Ethics Committee of the Faculty of Medicine, Tottori University (approval number 1607A033).

Informed Consent Statement: Not applicable.

Data Availability Statement: The datasets used and/or analyzed during the current study are available from the corresponding author on reasonable request.

Acknowledgments: We would like to thank Atsushi Shimizu (National Institute for Environmental Studies) for providing LIDAR data and Editage (www.editage.jp) for English-language editing.

Conflicts of Interest: The authors declare no conflict of interest.

\section{References}

1. World Health Organization. Available online: https:/ /www.who.int/airpollution/en/ (accessed on 18 February 2021).

2. World Health Organization. Ambient air Pollution: A global Assessment of Exposure and Burden of Disease. Available online: https:/ /apps.who.int/iris/bitstream/handle/10665/250141/9789241511353-eng.pdf?sequence=1 (accessed on 18 February 2021).

3. Guo, J.; Lou, M.; Miao, Y.; Wang, Y.; Zeng, Z.; Liu, H.; He, J.; Xu, H.; Wang, F.; Min, M.; et al. Trans-Pacific transport of dust aerosols from East Asia: Insights gained from multiple observations and modeling. Environ. Pollut. 2017, 230, 1030-1039. [CrossRef]

4. Coulibaly, S.; Minami, H.; Abe, M.; Hasei, T.; Sera, N.; Yamamoto, S.; Funasaka, K.; Asakawa, D.; Watanabe, M.; Honda, N.; et al. Seasonal fluctuations in air pollution in Dazaifu, Japan, and effect of long-range transport from mainland East Asia. Biol. Pharm. Bull. 2015, 38, 1395-1403. [CrossRef] [PubMed]

5. Ohizumi, T.; Akimoto, H.; Kanaya, Y.; Nagashima, T.; Sakurai, T.; Ohara, T.; Sato, K. Assessment of Japanese photochemical ozone pollution by 8-hour average concentrations. J. Jpn. Soc. Atmos. Environ. 2013, 48, 181-187.

6. Aas, W.; Mortier, A.; Bowersox, V.; Cherian, R.; Faluvegi, G.; Fagerli, H.; Hand, J.; Klimont, Z.; Galy-Lacaux, C.; Lehmann, C.M.B.; et al. Global and regional trends of atmospheric sulfur. Sci. Rep. 2019, 9, 953. [CrossRef] [PubMed]

7. Akimoto, H.; Mori, Y.; Sasaki, K.; Nakanishi, H.; Ohizumi, T.; Itano, Y. Analysis of monitoring data of ground-level ozone in Japan for long-term trend during 1990-2010: Causes of temporal and spatial variation. Atomos. Environ. 2015, 102, 302-310. [CrossRef]

8. Schwela, D. Air pollution and health in urban areas. Rev. Environ. Health. 2000, 15, 13-42. [CrossRef]

9. Ab Manan, N.; Noor, A.A.; Hod, R. Effect of air pollution and hospital admission: A systematic review. Ann. Glob. Health. 2018, 84, 670-678. [CrossRef]

10. Aghababaeian, H.; Ostadtaghizadeh, A.; Ardalan, A.; Asgary, A.; Akbary, M.; Yekaninejad, M.S.; Stephens, C. Global health impacts of dust storms: A systematic review. Environ. Health. Insights. 2021, 15, 11786302211018390. [CrossRef]

11. Schraufnagel, D.E.; Balmes, J.R.; Cowl, C.T.; De Matteis, S.; Jung, S.H.; Mortimer, K.; Perez-Padilla, R.; Rice, M.B.; Riojas-Rodriguez, H.; Sood, A.; et al. Air pollution and noncommunicable diseases: A review by the forum of international respiratory societies' environmental committee, Part 2: Air pollution and organ systems. Chest 2019, 155, 417-426. [CrossRef]

12. Nhung, N.T.T.; Amini, H.; Schindler, C.; Kutlar, J.M.; Dien, T.M.; Probst-Hensch, N.; Perez, L.; Künzli, N. Short-term association between ambient air pollution and pneumonia in children: A systematic review and meta-analysis of time-series and casecrossover studies. Environ. Pollut. 2017, 230, 1000-1008. [CrossRef]

13. Orellano, P.; Quaranta, N.; Reynoso, J.; Balbi, B.; Vasquez, J. Association of outdoor air pollution with the prevalence of asthma in children of Latin America and the Caribbean: A systematic review and meta-analysis. J. Asthma. 2018, 55, 1174-1186. [CrossRef]

14. Bateson, T.F.; Schwartz, J. Children's response to air pollutants. J. Toxicol. Environ. Health. 2008, A 71, 238-243. [CrossRef]

15. Zumel-Marne, A.; Castano-Vinyals, G.; Kundi, M.; Alguacil, J.; Cardis, E. Environmental factors and the risk of brain tumours in young people: A systematic review. Neuroepidemiology. 2019, 53, 121-141. [CrossRef] [PubMed]

16. Filippini, T.; Hatch, E.E.; Rothman, K.J.; Heck, J.E.; Park, A.S.; Crippa, A.; Orsini, N.; Vinceti, M. Association between outdoor air pollution and childhood leukemia: A systematic review and dose-response meta-analysis. Environ. Health. Perspect. 2019, 127, 46002. [CrossRef]

17. Noh, J.; Sohn, J.; Cho, J.; Cho, S.K.; Choi, Y.J.; Kim, C.; Shin, D.C. Short-term effects of ambient air pollution on emergency department visits for asthma: An assessment of effect modification by prior allergic disease history. J. Prev. Med. Public. Health. 2016, 49, 329-341. [CrossRef] [PubMed]

18. Hales, N.M.; Barton, C.C.; Ransom, M.R.; Allen, R.T.; Pope, C.A., 3rd. A quasi-experimental analysis of elementary school absences and fine particulate air pollution. Medicine. 2016, 95, e2916. [CrossRef] [PubMed] 
19. Chen, L.; Jennison, B.L.; Yang, W.; Omaye, S.T. Elementary school absenteeism and air pollution. Inhal. Toxicol. 2000, 12, 997-1016. [PubMed]

20. Zhang, Y.; Cui, L.; Xu, D.; He, M.Z.; Zhou, J.; Han, L.; Li, X.; Li, T. The association of ambient PM 2.5 with school absence and symptoms in schoolchildren: A panel study. Pediatr. Res. 2018, 84, 28-33. [CrossRef]

21. Wenten, M.; Gauderman, W.J.; Berhane, K.; Lin, P.C.; Peters, J.; Gilliland, F.D. Functional variants in the catalase and myeloperoxidase genes, ambient air pollution, and respiratory-related school absences: An example of epistasis in gene-environment interactions. Am. J. Epidemiol. 2009, 170, 1494-1501. [CrossRef]

22. Hwang, J.S.; Chen, Y.J.; Wang, J.D.; Lai, Y.M.; Yang, C.Y.; Chan, C.C. Subject-domain approach to the study of air pollution effects on schoolchildren's illness absence. Am. J. Epidemiol. 2000, 152, 67-74. [CrossRef] [PubMed]

23. Marcon, A.; Pesce, G.; Girardi, P.; Marchetti, P.; Blengio, G.; de Zolt Sappadina, S.; Falcone, S.; Frapporti, G.; Predicatori, F.; de Marco, R. Association between $\mathrm{PM}_{10}$ concentrations and school absences in proximity of a cement plant in northern Italy. Int. J. Hyg. Environ. Health. 2014, 217, 386-391. [CrossRef] [PubMed]

24. Zhang, Z.; Zhang, G.; Song, S.; Su, B. Spatial heterogeneity influences of environmental control and informal regulation on air pollutant emissions in China. Int. J. Environ. Res. Public. Health 2020, 17, 4857. [CrossRef] [PubMed]

25. Garcia, E.; Berhane, K.T.; Islam, T.; McConnell, R.; Urman, R.; Chen, Z.; Gilliland, F.D. Association of changes in air quality with incident asthma in children in California, 1993-2014. JAMA 2019, 321, 1906-1915. [CrossRef]

26. Tanaka, S. Environmental regulations on air pollution in China and their impact on infant mortality. J. Health. Econ. 2015, 42, 90-103. [CrossRef]

27. Onishi, K.; Kurosaki, Y.; Otani, S.; Yoshida, A.; Sugimoto, N.; Kurozawa, Y. Atmospheric transport route determines components of Asian dust and health effects in Japan. Atomos. Environ. 2012, 49, 94-102. [CrossRef]

28. Chen, Y.S.; Sheen, P.C.; Chen, E.R.; Liu, Y.K.; Wu, T.N.; Yang, C.Y. Effects of Asian dust storm events on daily mortality in Taipei, Taiwan. Environ. Res. 2004, 95, 151-155. [CrossRef] [PubMed]

29. Bell, M.L.; Levy, J.K.; Lin, Z. The effect of sandstorms and air pollution on cause-specific hospital admissions in Taipei, Taiwan. Occup. Environ. Med. 2008, 65, 104-111. [CrossRef]

30. Chan, C.C.; Chuang, K.J.; Chen, W.J.; Chang, W.T.; Lee, C.T.; Peng, C.M. Increasing cardiopulmonary emergency visits by long-range transported Asian dust storms in Taiwan. Environ. Res. 2008, 106, 393-400. [CrossRef]

31. Meng, Z.; Lu, B. Dust events as a risk factor for daily hospitalization for respiratory and cardiovascular disease in Minqin, China. Atoms. Environ. 2007, 41, 7048-7058. [CrossRef]

32. Kanatani, K.; Ito, I.; Al-Delaimy, W.K.; Adachi, Y.; Mathews, W.C.; Ramsdell, J.W. Desert-dust exposure is associated with increased risk of asthma hospitalization in children. Am. J. Respir. and Crit. Med. 2010, 182, 1475-1481. [CrossRef]

33. Schwartz, J. Air pollution and children's health. Pediatrics. 2004, 113, 1037-1043. [PubMed]

34. Sugimoto, N.; Lee, C.H. Characteristics of dust aerosols inferred from lidar depolarization measurements at two wavelengths. Applied. Optics. 2006, 45, 7468-7474. [CrossRef] [PubMed]

35. Sugimoto, N.; Matsui, I.; Shimizu, A. Lidar network observations of tropospheric aerosols. Proc. SPIE. 2008, 7153. [CrossRef]

36. Carracedo-Martínez, E.; Taracido, M.; Tobias, A.; Saez, M.; Figueiras, A. Case-crossover analysis of air pollution health effects: A systematic review of methodology and application. Environ. Health. Perspect. 2010, 118, 1173-1182. [CrossRef] [PubMed]

37. Janes, H.; Sheppard, L.; Lumley, T. Case-crossover analyses of air pollution exposure data: Referent selection strategies and their implications for bias. Epidemiology. 2005, 16, 717-726. [CrossRef] [PubMed]

38. Armstorong, B.G.; Gasparrini, A.; Tobias, A. Conditional Poisson models: A flexible alternative to conditional logistic case cross-over analysis. BMC. Med. Res. Methodol. 2014, 14, 122. [CrossRef]

39. Sugimoto, N.; Uno, I.; Nishikawa, M.; Shimizu, A.; Matsui, I.; Dong, X.; Chen, Y.; Quan, H. Record heavy Asian dust in Beijing in 2002: Observations and model analysis of recent events. Geophys. Res. Lett. 2003, 30, 1640. [CrossRef]

40. Ikeda, K.; Yamaji, K.; Kanaya, Y.; Taketani, F.; Pan, X.; Komazaki, Y.; Kurokawa, J.; Ohara, T. Source region attribution of PM 2.5 mass concentration over Japan. Geochemical. Journal. 2015, 49, 185-194. [CrossRef]

41. Bowatte, G.; Lodge, C.; Lowe, A.J.; Erbas, B.; Perret, J.; Abramson, M.J.; Matheson, M.; Dharmage, S.C. The influence of childhood traffic-related air pollution exposure on asthma, allergy and sensitization: A systematic review and a meta-analysis of birth cohort studies. Allergy. 2015, 70, 245-256. [CrossRef]

42. Friedrich, M.J. Global impact of air pollution on children's health. JAMA. 2018, 320, 2412. [CrossRef]

43. Chen, Y.; Zheng, M.; Lv, J.; Shi, T.; Liu, P.; Wu, Y.; Feng, W.; He, W.; Guo, P. Interactions between ambient air pollutants and temperature on emergency department visits: Analysis of varying-coefficient model in Guangzhou, China. Sci. Total. Environ. 2019, 668, 825-834. [CrossRef] [PubMed]

44. Sun, S.; Cao, W.; Mason, T.G.; Ran, J.; Qiu, H.; Li, J.; Yang, Y.; Lin, H.; Tian, L. Increased susceptibility to heat for respiratory hospitalizations in Hong Kong. Sci. Total. Environ. 2019, 666, 197-204. [CrossRef] [PubMed] 